Case report

\title{
Traumatic false aneurysm of the distal peroneal artery with associated anatomic anomaly: a case report Michael J Ramdass
}

Address: Department of Surgery, General Hospital, Port-of-Spain, Trinidad, West Indies

Email: jimmyramdass@gmail.com

Received: 7 December 2008 Accepted: 17 June 2009 Published: 20 July 2009

Cases Journal 2009, 2:8605 doi: 10.4076/1757-1626-2-8605

This article is available from: http://casesjournal.com/casesjournal/article/view/8605

(C) 2009 Ramdass; licensee Cases Network Ltd.

This is an Open Access article distributed under the terms of the Creative Commons Attribution License (http://creativecommons.org/licenses/by/3.0), which permits unrestricted use, distribution, and reproduction in any medium, provided the original work is properly cited.

\begin{abstract}
Football and ankle soft tissue injuries are common occurrences. However, traumatic peroneal false aneurysm is quite a rare entity with only a handful of cases reported in the literature. A case of traumatic false aneurysm of the distal peroneal artery is described in which an anatomic anomaly of the distal peroneal artery crossing the ankle joint may have been a predisposing factor. A technique for surgical approach is also described for the particular location of the lesion.
\end{abstract}

\section{Case presentation}

A 20-year-old Trinidadian gentleman of african-descent presented to orthopaedics after sustaining an injury to the right ankle whilst playing football. The injury involved inversion of the ankle joint with pain, swelling and tenderness in the region of the lateral malleolus. There was no notable neurovascular injury and radiographs were normal. The patient was advised rest and elevation and the joint immobilised for 2 weeks. At the first outpatient visit, it was noted that a pulsatile swelling had developed in the region of the lateral malleolus and the skin over the swelling was partially necrotic. A diagnosis of a false aneurysm was made and confirmed on duplex scanning. A magnetic resonance angiogram (MRA) with gadolinium contrast of the right lower limb revealed a false aneurysm of one of the terminal branches of the peroneal artery. In addition the peroneal artery was found to be anomalous, crossing the ankle joint and consisting of several large branches forming an anastomosis in the region (Figure 1).

Immediate exploration of the false aneurysm was undertaken via a longitudinal incision in the region of the lateral malleolus with digital pressure to control bleeding and the fine distal feeding vessel oversewn with a 5.0 prolene suture (Figure 2). Haemostasis was achieved and the wound closed (Figure 3). The necrotic skin of the region eventually sloughed and formed an ulcer, which slowly but fully healed over a 3-month period. The patient made an uneventful recovery.

\section{Discussion}

True aneurysms of the peroneal artery are extremely rare with isolated reports of cases related to mycotic aneurysms [1] or connective tissue disorders such as Behcet's disease [2]. Mycotic pseudoaneurysms typically involve major axial vessels proximal to the popliteal artery, however, there is an association with the tibioperoneal vessels in infective endocarditis, brucella canis [1] and gram-positive pathogens in intravenous drug Abusers [3]. A search of the literature reveals a handful of cases and one review of false aneurysms documented in various scenarios [15]. Trauma to the leg or ankle is the most common cause of such pseudoaneurysms specifically of the peroneal artery. It has been documented in ankle sprain/soft tissue injury, 


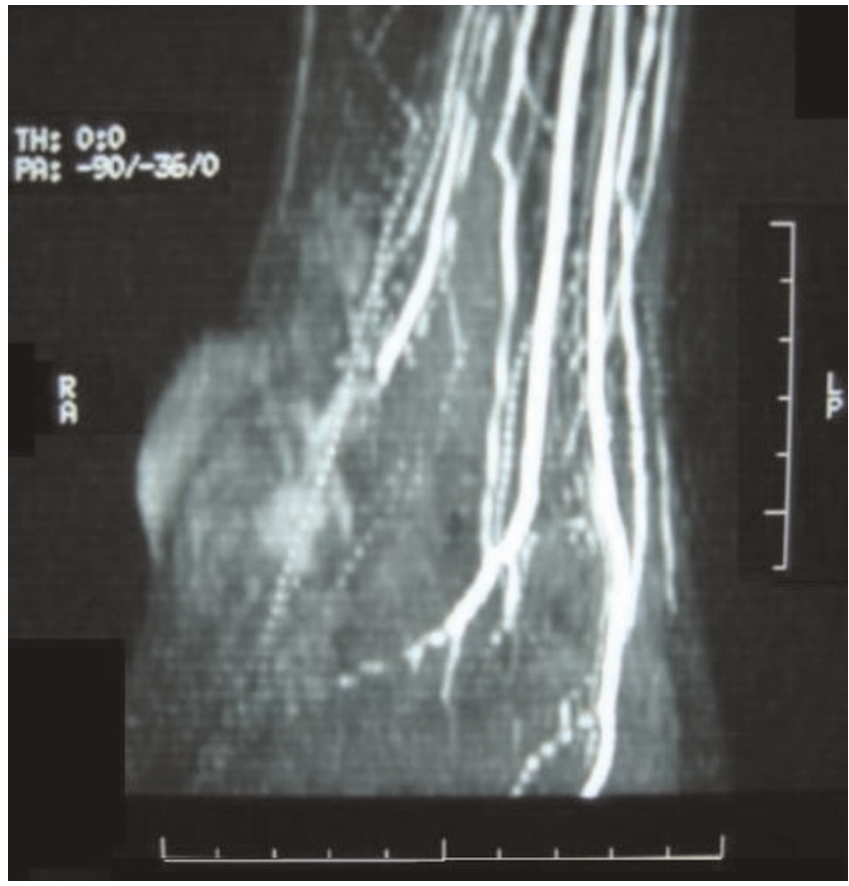

Figure I. Anomalous peroneal artery, crossing the ankle joint and consisting of several large branches forming an anastomosis in the region with associated false aneurysm.

penetrating or blunt injury and malleolar fracture of the ankle [4-6]. Iatrogenic causes have also been described including thrombo-embolectomy using a fogarty balloon catheter [7] or after femoro-peroneal bypass grafting [8].

Management has traditionally been surgical, however, peroneal pseudoaneurysms may thrombose spontaneously

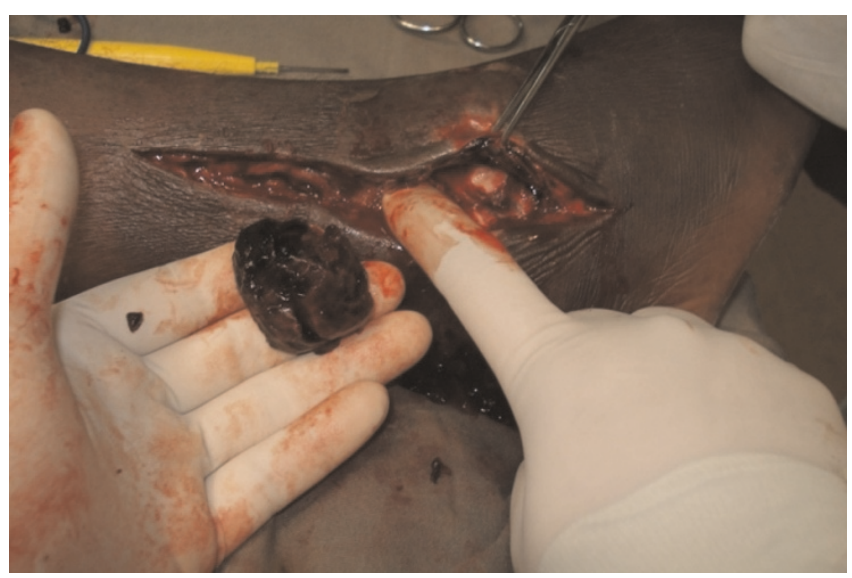

Figure 2. Exploration of the false aneurysm via longitudinal incision in the region of the lateral malleolus with digital pressure to control bleeding.

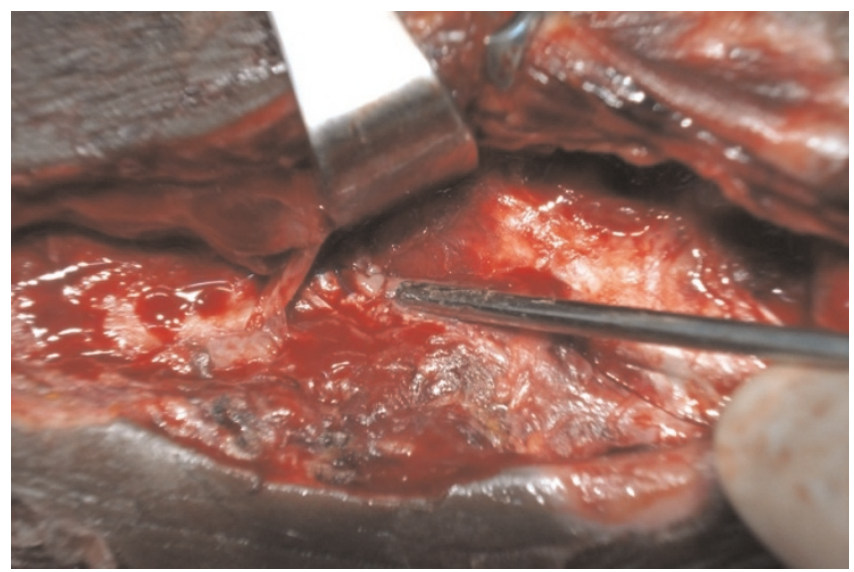

Figure 3. Distal feeding vessel oversewn with a 5.0 prolene suture.

$[9,10]$. Since the advent of modern techniques in interventional radiology it is now becoming more acceptable to perform coil embolization [11,12], thrombin injection [13] or stent insertion [14].

Surgical management involves the evacuation of the haematoma after proximal and distal vascular control has been achieved. The defect in the arterial wall can either be repaired by primary closure or by insertion of a vein patch. Vein interposition graft or prosthetic graft can also be used if the segment of the disrupted artery cannot be primarily repaired.

In this particular case there are two important learning points. Firstly, due to the location of this pseudoaneurysm just postero-inferior to the lateral malleolus it was technically challenging to get proximal control. Therefore, the procedure was done using pure digital control of the peroneal artery just proximal to the injured vessel branch. For extra safety a tourniquet was applied to the thigh, but not inflated as extra insurance in the event that digital control was insufficient.

The second point is noted on MRA in which there was an anatomical anomaly of the peroneal artery. The vessel appeared to cross the ankle joint and to have several large branches, which may have accounted for the injury to the vessel in this particular case.

It is recommended that an MRA or CTA be done prior to exploration for distal peroneal false aneurysms for two reasons; to define anatomy and plan surgical approach, since the vessel may not always be easily accessible and to document and possibly correlate anatomic anomalies of the vessel with this injury for future reference. 


\section{Abbreviations}

MRA, Magnetic Resonance Angiogram; CTA, Computed Tomography Angiogram.

\section{Consent}

Written informed consent was obtained from the patient for publication of this case report and accompanying images. A copy of the written consent is available for review by the Editor-in-Chief of this journal.

\section{Competing interests}

The author declares that he has no competing interest.

\section{References}

I. McKee MA, Ballard JL: Mycotic aneurysms of the tibioperoneal arteries. Ann Vasc Surg 1999, 13:188-190.

2. Toyota N, Kimura F, Yoshida S, Mitsui N, Mochizuki T, Naito A, Ito K: Peroneal artery aneurysm treated by transcatheter coil embolization and temporary balloon occlusion in Behcet's disease. Cardiovasc Intervent Radiol 1999, 22:257-259.

3. Brown SL, Busuttil RW, Baker JD, Machleder HI, Moore WS, Barker WF: Bacteriologic and surgical determinants of survival in patients with mycotic aneurysms. J Vasc Surg 1984, I:54 I-547.

4. Maguire DW, Huffer JM, Ahlstrand RA, Crummy AB Jr: Traumatic aneurysm of perforating peroneal artery. Arterial bleeding cause of severe pain following inversion, plantar flexion, ankle sprains. J Bone Joint Surg Am 1972, 54:409-4I2.

5. Rainey RK, Andersen C, Sehorn S, Sears S: Traumatic false aneurysm of the ankle. A case report. Clin Orthop Relat Res 1983, 176:163-165.

6. Pai VS: Traumatic aneurysm of the perforating peroneal artery following ankle fracture. J Foot Ankle Surg 1999, 38:417-419.

7. Sugimoto $T$, Kitade $T$, Morimoto $N$, Terashima $K$ : Pseudo aneurysms of peroneal artery: treatment with transcatheter platinum coil embolization. Ann Thorac Cardiovasc Surg 2004, 10:263-265.

8. Parry DJ, Kessel D, Scott DJ: False aneurysm of the peroneal artery: an unusual complication of femoro-peroneal bypass grafting. Cardiovasc Surg 2002, 10:54-57.

9. Upponi SS, Solan M: Spontaneous resolution of a traumatic false aneurysm of the peroneal artery. Injury 1998, 29:787-788.

10. Kocakoc E, Bozgeyik Z, Ozgocmen S, Ozdemir H: Spontaneous occlusion of a traumatic false aneurysm of the peroneal artery. J Ultrasound Med 2003, 22:139|-1393.

II. Albrecht RJ, Parra JR: Traumatic peroneal artery pseudoaneurysm: use of preoperative coil embolization. J Vasc Surg 2004, 39:912.

12. Rosa P, O'Donnell SD, Goff JM, Gillespie DL, Starnes B: Endovascular management of a peroneal artery injury due to a military fragment wound. Ann Vasc Surg 2003, 17:678-68I.

13. Grewe PH, Mugge A, Germing A, Harrer E: Occlusion of pseudoaneurysms using human or bovine thrombin using contrast-enhanced ultrasound guidance. Am J Cardiol 2004, 93:1540-1542.

14. Vaidhyanath R, Blanshard KS: Treatment of a popliteal artery pseudoaneurysm. Radiol 2003, 76:195-198.

15. Sadat U, See T, Cousins C, Hayes P, Gaunt M: Peroneal artery pseudoaneurysm - a case report and literature review. $B M C$ Surg 2007, 7:4.

\section{Do you have a case to share?}

\section{Submit your case report today}

- Rapid peer review

- Fast publication

- PubMed indexing

- Inclusion in Cases Database

\section{Any patient, any case, can teach us something}

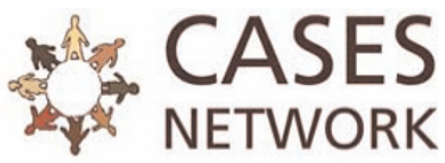

www.casesnetwork.com 